\title{
ASSESSMENT OF THE SERUM LEVEL OF COMPLEMENT C3 AND C4 IN CHRONIC VIRAL HEPATITIS C INFECTION AND THEIR CORRELATION WITH RESPONSE TO DIRECT ACTING ANTI-VIRAL AGENTS
}

\author{
By
}

\section{Mohamed Abd El-wahed Ramadan', Sabah Ibrahim Abd El-Rehiem², Ahmad Al-Saeed Al-Sehrawy ${ }^{3}$ and Mohamed Hieza ${ }^{4}$}

${ }^{1}$ Department of Clinical Pathology, Damietta Faculty of Medicine, Al-Azhar University, Egypt

${ }^{2}$ Department of Clinical Pathology, Faculty of Medicine for Girls, Al-Azhar University, Egypt

${ }^{3}$ Department of Clinical Pathology, Faculty of Medicine, Al-Azhar University, Egypt

${ }^{4}$ Department of Hepatology, Gastroenterology and Infectious diseases, Damietta Faculty of Medicine, Al-Azhar University, Egypt

Corresponding author: Mohamed Abd El-Wahed Ramadan

E-mail: dr.mohamedabdelwahed92@gmail.com

\begin{abstract}
Background: The interactions between hepatitis C Virus (HCV) and the host immune system have a major role in $\mathrm{HCV}$ pathogenesis.

Objective: To estimate complement $\mathrm{C} 3$ and $\mathrm{C} 4$ serum levels in patients with chronic $\mathrm{HCV}$ patients and to correlate its levels with response to directly acting anti-viral agents (DAAs) in those patients.

Patients and methods: The study included 80 individuals classified into two groups: Group (I): 40 patients with chronic HCV infection, Group (II): Control group which included 40 healthy individuals. Measurement of the level of complement C3 and C4 has done by nephelometry immunoassay before and after treatment with DAAs.
\end{abstract}

Results: All patients with chronic HCV infection in group (I) showed significant reduction in serum levels of complement C3 and C4 compared to the control group (II). Moreover, those patients who treated with DAAs showed significantly higher levels of $\mathrm{C} 3$ and $\mathrm{C} 4$ when compared to chronic HCV patients before treatment with DAAs.

Conclusion: Serum levels of complement C3 and C4 serum may be used in the follow up of the course of the disease and may be used as a predictor for the response to treatment with DAAs.

Keywords: Hepatitis C, Complement, Response, Antivirals, Viral load. 


\section{INTRODUCTION}

Hepatitis C infection (HCV) disease could be a driving cause of liver-related mortality and mortality, and it speaks to a critical compassionate and healthcare burden all over the world. The Polaris Observatory estimates that 71 million individuals around the world are infected with HCV (Crespo et al., 2020).

Chronic HCV infection tends to progress to liver fibrosis and cirrhosis. Subsequently, hepatocellular carcinoma can develop in the context of bridging fibrosis (F3 by Metavir) or liver cirrhosis (F4 by Metavir). Decompensated liver cirrhosis together with hepatocellular carcinoma is considered the most common cause of death associated with chronic HCV infection (Webster et al., 2015).

These days, chronic HCV infection is considered a systemic disease, whereas it does not affect only the liver, but other organs as well. About three-quarters of patients moreover suffer from extrahepatic signs, which can appear before chronic HCV diagnosis. Diabetes mellitus sort 2 (T2DM) is one of the foremost common extra-hepatic signs of chronic $\mathrm{HCV}$ infection. In addition, $\mathrm{HCV}$ accelerates atherogenesis and is also related with cardiovascular diseases (Vanni et al., 2015).

$\mathrm{HCV}$ infection not only increases liver disease mortality rate but also cardiovascular leading mortality rate. The essential objective of chronic $\mathrm{HCV}$ disease treatment is to attain sustained viral reaction (SVR), characterized by the total disappearance of HCV from patient's body. SVR is related with diminished liver disease mortality rate along with all- leading cause's mortality rate(van der Meer et al., 2012).

There has been a surprising breakthrough within the treatment of chronic $\mathrm{HCV}$ disease, within the frame of the usage of direct-acting antivirals (DAAs) into clinical practice guidelines. Using a combination of at least two of DAAs, specifically NS5A inhibitor, NS5B inhibitor, or NS3/4a protease inhibitor, results in a very high response rate (Asselah and Marcellin, 2012).

The complement system is made up of a large number of distinct plasma proteins and is considered one of the most important weapons of innate immunity which involved in all infectious processes. The Activation process of complement is the cause of strong and productive proteolytic cascades, which end in opsonization and lysis of the pathogen as well as within the generation of the classical inflammatory reaction through the generation of powerful proinflammatory particles (Dunkelberger and Song, 2011).

It is not only an instrument for direct protection against an attacking pathogen, but it also interacts with the adaptive immunity to optimize the pathogenspecific humoral and cellular defense components within the body (Hakobyan et al., 2016).

The association of complement within the course of HCV disease has been poorly recorded. A couple of studies show changes within the acute stage complement elements in $\mathrm{HCV}$ patients accepting interferon alpha $2 b$ or an association between $\mathrm{HCV}$ infection and a cold-dependent activation of the classical 


\section{ASSESSMENT OF THE SERUM LEVEL OF COMPLEMENT C3 AND C4...}

pathway or hypocomplementemia related with cryoglobulinemia (Mazumdar et al., 2012).

This study aimed to estimate complement $\mathrm{C} 3$ and $\mathrm{C} 4$ serum levels in patients with chronic $\mathrm{HCV}$ infection and to correlate its levels with response to treatment with DAAs in these patients.

\section{PATIENTS AND METHODS}

This study was a case control study which had been conducted at Gastroenterology and Infectious diseases Department of New Damietta Hospital of Al-Azhar University.

Forty participants who diagnosed as chronic HCV patients were selected from outpatient clinic and inpatient of Hepatology. Forty healthy individuals matched for age and sex were selected as a control group. Informed consent for participation in the study was obtained from all patients and controls.

The study populations were classified into two groups. Group (I) 40 patients with chronic $\mathrm{HCV}$ infection and Group (II) "Control group" which included 40 healthy individuals matched for age and sex.

Patients with any history of diseases leading to affection of complement $\mathrm{C} 3$ and $\mathrm{C} 4$ levels, as autoimmune, allergic or infectious diseases were excluded from the study.

All included subjects submitted to full history taking, general and local examination, radiological investigations and laboratory investigations including complete blood count (CBC), liver function tests, kidney function tests, erythrocyte sedimentation rate (ESR), prothrombin time (PT) andinternational normalized ratio (INR). Also, viral markers (HBsAg \& HCVAb) and HCVRNA by polymerase chain reaction (PCR) were estimated.

C3 and C4 concentrations were measured in sera by nephelometry immunoassay by $\mathrm{C} 3$ and $\mathrm{C} 4$ commercial kits (Agappe Diagnostics Switzerland Gmbh). The normal standardized values for each component were $90-180 \mathrm{mg} / \mathrm{dl}$ and $9-36 \mathrm{mg} / \mathrm{dl}$, respectively.

\section{Statistical analysis:}

All data statistically analyzed using SPSS 22.0. Chi square test $(\chi 2)$ and Fisher exact was used for qualitative data. Quantitative data were expressed as mean \pm SD (Standard deviation) for parametric and median and range for non-parametric data. Independent $\mathrm{T}$ test and Mann Whitney test were used to calculate difference between quantitative variables for parametric and non-parametric variables respectively. Paired t-test was used for normally distributed variables while Wilcoxon signed ranks test was used for non-normally distributed variables. Pearson's or Spearman's correlation coefficients were used for correlating normal and non-parametric variables respectively. Receiver operating characteristic (ROC) curve was constructed to permit selection of threshold values for test results and comparison of different testing strategies. Level of significance wad considered when $\mathrm{P}<0.05$. 


\section{RESULTS}

There was a significant increase in alanine aminotransferase (ALT), aspartate amino transferees (AST), total bilirubin, gama glutamyl transferase (GGT) and ESR and significant decrease in hemoglobin, total leucocytic count (TLC), platelets, albumin, C3 and C4 levels in group (I) when compared with group (II). There was no statistically significant difference between the two groups regarding to Creatinine, Urea and (INR)

(Table 1).

After treatment with DAAs, $100 \%$ of patients were found to be responders to DAAs at the end of treatment evidenced by negative PCR test for HCV RNA in serum. The clinical findings and laboratory values changes were compared before and after the treatment. There was no statistical differences between before and after treatment regarding liver cirrhosis and splenomegaly and there was statistically significant difference regarding to jaundice $(\mathrm{P}=0.011)$, lower limb edema $(\mathrm{P}=0.004)$, and ascites $(\mathrm{P}=$ $0.030)$. There was a significant decrease in ALT, AST, total bilirubin and GGT and significant increase in hemoglobin, TLC, albumin, C3 and C4 levels after treatment. There were no statistically significant changes regarding to Platelets, Creatinine, Urea and INR (Table 1).

Table (1): Comparison between laboratory parameters in group I and group II $($ Mean \pm SD)

\begin{tabular}{|l|c|c|c|c|}
\hline \multirow{2}{*}{ Groups } & \multicolumn{2}{c|}{$\begin{array}{c}\text { Group (I) } \\
\text { Parameters }\end{array}$} & \multirow{2}{*}{$\begin{array}{c}\text { Group (II) } \\
(\mathbf{N}=\mathbf{4 0})\end{array}$} & \multirow{2}{*}{ P- value } \\
\cline { 2 - 3 } & $\begin{array}{c}\text { Before } \\
\text { Treatment }\end{array}$ & $\begin{array}{c}\text { After } \\
\text { Treatment }\end{array}$ & & \\
\hline Hb $(\mathrm{g} / \mathrm{dL})$ & $10.2 \pm 1.6$ & $11.1 \pm 1.3$ & $13.2 \pm 1.2$ & $\mathbf{0 . 0 0 1}$ \\
\hline TLC $(\mathrm{x} \mathrm{10} / \mathrm{L})$ & $3.2 \pm 2.1$ & $3.6 \pm 1.8$ & $6.9 \pm 1.7$ & $\mathbf{0 . 0 0 1}$ \\
\hline PLT $(\mathrm{x} \mathrm{10} / \mathrm{s} / \mathrm{L})$ & $135 \pm 49$ & $140 \pm 41$ & $263 \pm 59$ & $\mathbf{0 . 0 0 1}$ \\
\hline ALT(U/L) & $76 \pm 25$ & $43.1 \pm 18.54$ & $21 \pm 6$ & $\mathbf{0 . 0 0 1}$ \\
\hline AST(U/L) & $102 \pm 25$ & $67 \pm 16$ & $23 \pm 6$ & $\mathbf{0 . 0 0 1}$ \\
\hline Total bilirubin(mg/dl) & $2.4 \pm 0.7$ & $1.6 \pm 0.8$ & $0.6 \pm 1.6$ & $\mathbf{0 . 0 0 1}$ \\
\hline Albumin(g/dl) & $2.6 \pm 0.4$ & $3.7 \pm 0.4$ & $4.3 \pm 0.5$ & $\mathbf{0 . 0 0 1}$ \\
\hline GGT(U/L) & $67 \pm 10$ & $53 \pm 13$ & $19 \pm 7$ & $\mathbf{0 . 0 0 1}$ \\
\hline Creatinine(mg/dl) & $0.7 \pm 0.17$ & $0.8 \pm 0.2$ & $0.8 \pm 0.17$ & 0.73 \\
\hline Urea $(\mathrm{mg} / \mathrm{dl})$ & $25 \pm 5$ & $28 \pm 4$ & $28 \pm 4$ & 0.23 \\
\hline INR & $1.15 \pm 0.046$ & $1.15 \pm 0.071$ & $1.06 \pm 0.065$ & 0.81 \\
\hline ESR $(\mathrm{mm} / \mathrm{hr})$ & $61 \pm 33$ & $56 \pm 24$ & $11 \pm 4$ & $\mathbf{0 . 0 0 1}$ \\
\hline C3 $(\mathrm{mg} / \mathrm{dL})$ & $44.9 \pm 17.3$ & $85.8 \pm 14.0$ & $140.7 \pm 19.5$ & $\mathbf{0 . 0 0 1}$ \\
\hline C4 $(\mathrm{mg} / \mathrm{dL})$ & $5.5 \pm 1.51$ & $14.8 \pm 4.3$ & $25.8 \pm 6.6$ & $\mathbf{0 . 0 0 1}$ \\
\hline
\end{tabular}

Hb: Hemoglobin; TLC: Total Leucocytic Count; PLT: Platelets; ALT: Alanine Aminotransferase; AST: Aspartate Aminotransferase; GGT: Gama Glutamyl Transferase; INR: International Normalized Ratio; ESR: Erythrocyte sedimentation rate; $\mathrm{C}$ 3: Complement C3; C4: Complement C4.

There was a significant negative correlation between $\mathrm{C} 3$ \& $\mathrm{C} 4$ with platelets count, ALT, AST, total bilirubin and ESR, while there is a significant positive correlation with age. Meanwhile, there is a significant positive correlation 


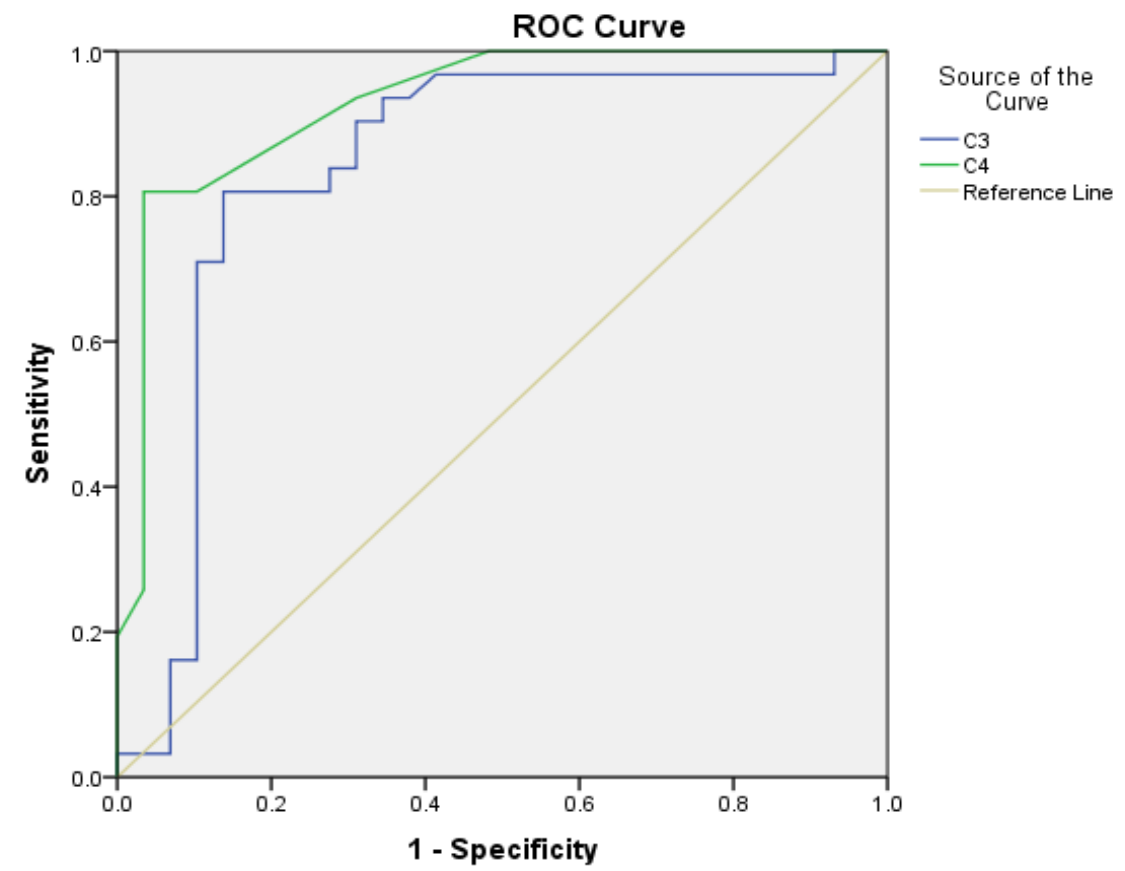

between $\mathrm{C} 3$ and C4.ROC curve of $\mathrm{C} 3$ and $\mathrm{C} 4$ showed positive correlation for

predicting response to DAAs in chronic HCV patients (Figure 1).

Figure (1): $\quad$ ROC curve of $\mathrm{C} 3$ and $\mathrm{C} 4$ for predicting response to DAAs in chronic HCV patients

C3 was significant at cut off level of $77.65 \mathrm{mg} / \mathrm{dl}$ with sensitivity $91.6 \%$ and specificity $86.2 \%$, while $\mathrm{C} 4$ was significant at cut off level of $11.87 \mathrm{mg} / \mathrm{dl}$ with sensitivity $93.5 \%$ and specificity $89.7 \%$ (Table 2).

Table (2): $\mathrm{C} 3 \& \mathrm{C} 4$ was cut off level

\begin{tabular}{|c|c|c|c|c|c|}
\hline Variable(s) & AUC & Sig. & $\begin{array}{c}\text { 95\% Confidence } \\
\text { Interval }\end{array}$ & Sensitivity & Specificity \\
\hline $\mathbf{C 3} \geq 77.65 \mathrm{mg} / \mathrm{dl}$ & .838 & $\mathbf{. 0 0 1}$ & $0.723-0.953$ & $91.6 \%$ & $86.2 \%$ \\
\hline $\mathbf{C 4} \geq 11.87 \mathrm{mg} / \mathrm{dl}$ & .928 & $\mathbf{. 0 0 1}$ & $0.861-0.995$ & $93.5 \%$ & $89.7 \%$ \\
\hline
\end{tabular}

C3: Complement C3; C4: Comlement C4; AUC: Area under Curve; Sig: Significant

\section{DISCUSSION}

Our study has conducted on 80 individuals, divided into two groups as follow: Group (I) "patients with chronic $\mathrm{HCV}$ infection. Group (II) "Control group" included 40 healthy individuals matched for age and sex.

Regarding to hematological findings, our study found that HCV patients had a significantly lower values of TLC, $\mathrm{Hb}$ and platelets compared to control Group. Moreover, patients after treatment with DAAs showed a significantly higher level of TLC and $\mathrm{Hb}$ than before treatment. There were no significant differences between before and after treatment regarding to platelets. Ruane et al. (2015) found increase platelet count after destruction of HCV by DDAs. With the removal of the viral load, platelets increased, and the antibodies disappeared. 
However, Honma et al. (2019) reported initial decrease in platelets count at 4 weeks then platelet increase at 12 weeks and started to decrease again to reach lower level at 36 weeks.

$\mathrm{HCV}$ patients had significantly higher values of ALT, AST, total bilirubin and GGT and lower values of albumin compared to control Group. Moreover, patients after treatment with DAAs showed significantly lower values of ALT, AST, total bilirubin and GGT and higher values of albumin than before treatment.

Our results also were supported by study of Chi et al. (2019) who found a highly significant difference as regard to liver function tests. There was marked increase in liver enzymes in chronic HCV patients which improved after treatment. Iliescu et al. (2020) reported that liver functions improved for those subjects that presented high transaminase levels after only one month from the therapy beginning, achieving stabilization of the parameters. Essa et al. (2019) revealed that serum albumin, prothrombin time, bilirubin, $\alpha$-fetoprotein, and alanine aminotransferase improved in treated patients.

Complement $\mathrm{C} 3$ and $\mathrm{C} 4$ in our study showed that HCV patients had significantly lower values of C3 and C4 compared to control Group. Moreover, patients after treatment with DAAs showed a significantly higher level of $\mathrm{C} 3$ and $\mathrm{C} 4$ than before treatment. This may point to the significance of Complement components $\mathrm{C} 3$ and $\mathrm{C} 4$ within the immune reaction against $\mathrm{HCV}$ and its function in the of $\mathrm{HCV}$ infection disposal. This observation may moreover lead to the hypothesis that $\mathrm{C} 3$ and $\mathrm{C} 4$ serum concentrations which can utilized as an indicator for great reaction to treatment with DAAs in chronic HCV patients. Mazumdar et al. (2012) reported that sera from patients chronically tainted with HCV showed significantly lower C3 levels than sera from healthy people. They recommended that $\mathrm{HCV}$ center protein showed a frail suppression of $\mathrm{C} 3$ promoter action by down regulating the translation figure foresaid $\mathrm{X}$ receptor (FXR).

Banerjee et al. (2011) found that C4 action has been showed to be was significantly lower in patients with chronic HCV diseases. Hassan et al. (2018) determined C3 and C4 components of complement concentrations before and after treatment with DAAs. Both C3 and $\mathrm{C} 4$ decreased among patients with chronic HCV. However, during therapy with DAAs; levels of both proteins increased and achieved higher levels.

Bunchorntavakul et al. (2018) started that development of specific $\mathrm{C} 4$ action after 6 months of treatment showed up to be an curiously basis for recognizing between responder and non-responder patients. In non-responders, the determination of viral RNA is related with the presence of cryoglobulins, which have been found in $49 \%$ of patients some time recently treatment with DAAs and in $76 \%$ of non-responders. They recommended that complement activation in chronic $\mathrm{HCV}$ does not appear to include the $\mathrm{C} 1$ stage of the classical pathway. They reported a negative relationship between particular C4 movement and rheumatoid factor (RF) titres which may point to a possible association of $\mathrm{RF}$ in $\mathrm{C} 4$ activation, through the lectin pathway. 


\section{ASSESSMENT OF THE SERUM LEVEL OF COMPLEMENT C3 AND C4...}

In our study, there was a significant negative correlation between C3 \& C4 with platelets count, ALT, AST, total bilirubin and ESR, while there was a significant positive correlation with age. Meanwhile, there was a significant positive correlation between $\mathrm{C} 3$ and $\mathrm{C} 4$. C3 was significant at cut off level of 77.65 $\mathrm{mg} / \mathrm{dl}$ with sensitivity $91.6 \%$ and specificity $86.2 \%$, while $\mathrm{C} 4$ was significant at cut off level of $11.87 \mathrm{mg} / \mathrm{dl}$ with sensitivity $93.5 \%$ and specificity 89.7\%. El-Fatah et al. (2014) observed the negative relationship between the level of $\mathrm{C} 3$ and $\mathrm{C} 4$ and ALT concentration in both groups. Bugdaci et al. (2012) observed the negative relationship between serum complement $\mathrm{C} 3$ levels and laboratory tests, HCV-RNA levels, histological action index, or fibrosis scores in patients with high transaminase levels, whereas complement $\mathrm{C} 4$ levels showed significant correlation with ALT and histological activity index.

\section{CONCLUSION}

$\mathrm{C} 3$ and $\mathrm{C} 4$ serum concentration may be used in the follow up of the course of the disease and prediction for the response to treatment with direct acting anti-viral agents.

\section{Financial and Non-Financial Relationships and Activities of Interest:}

None declared by the authors.

\section{REFERENCES}

1. Asselah $T$ and Marcellin $P$ (2012): Direct acting antivirals for the treatment of chronic hepatitis C: one pill a day for tomorrow. Liver Int., 32: 88-102.

2. Banerjee A, Mazumdar B, Meyer K, Di Bisceglie AM, Ray RB and Ray R (2011): Transcriptional repression of $\mathrm{C} 4$ complement by hepatitis C virus proteins. J Virol., 85(9):4157-66.

3. Buğdaci MS, Karaca C, Alkim C, Kesıcı B, Bayraktar B and Sökmen M (2012): Serum complements $\mathrm{C} 4$ in chronic hepatitis $\mathrm{C}$ : correlation with histopathologic findings and disease activity. Turk J Gastroenterol., 23(1):33-7.

4. Bunchorntavakul $C$, Mitrani $R$ and Reddy KR (2018): Advances in HCV and Cryoglobulinemic Vasculitis in the Era of DAAs: Are We at the End of the Road? J Clin Exp Hepatol., 8(1):81-94.

5. Chi CT, Chen CY, Su CW, Chen PY, Chu CJ, Lan KH, Lee IC and Hou MC (2019): Direct-acting antivirals for patients with chronic hepatitis $\mathrm{C}$ and hepatocellular carcinoma in Taiwan. J Microbiol Immunol Infect., 14:1182-1186.

6. Crespo J, Cuadrado A, Perelló C, Cabezas J, Llerena S, Llorca J, Cedillo S and Llop E (2020): Epidemiology of hepatitis $C$ virus infection in a country with universal access to direct-acting antiviral agents: Data for designing a cost-effective elimination policy in Spain. J Viral Hepat., 27(4):360-370.

7. Dunkelberger JR and Song WC. (2011): Complement and its role in innate and adaptive immune responses. Cell Res., 20(1):34-50.

8. El-Fatah Fahmy Hanno A, Mohiedeen KM, Deghedy A and Sayed R (2014): Serum complements $\mathrm{C} 3$ and $\mathrm{C} 4$ in chronic $\mathrm{HCV}$ infection and their correlation with response to pegylated interferon and ribavirin treatment. Arab J Gastroenterol., 15(2):58-62.

9. Essa M, Sabry A, Abdelsameea E, Tharwa ES and Salama $M$ (2019): Impact of new direct-acting antiviral drugs on hepatitis $\mathrm{C}$ virus-related decompensated liver cirrhosis. Eur J Gastroenterol Hepatol., 31(1):53-58.

10. Hakobyan S, Harding K, Aiyaz M, Hye A, Dobson R, Baird A, Liu B and Harris CL (2016): Complement Biomarkers as Predictors of Disease Progression in Alzheimer's Disease. J Alzheimers Dis., 54(2):707-16.

11. Hassan AM, Osman HA, Mahmoud HS, Hassan MH, Hashim AA and Ameen HH (2018): Sofosbuvir-daclatasvir improves 
hepatitis $\mathrm{C}$ virus-induced mixed cryoglobulinemia: Upper Egypt experience. Infect Drug Resist., 11:895-901.

12. Honma Y, Shibata M, Hayashi T, Kusanaga M, Ogino N, Minami S, Kumei S and Oe S (2019): Effect of direct-acting antivirals on platelet-associated immunoglobulin $\mathrm{G}$ and thrombocytopenia in hepatitis $\mathrm{C}$ virus-related chronic liver disease. Liver Int., 39(9):16411651.

13. Iliescu EL, Mercan-Stanciu A and Toma $\mathbf{L}$ (2020): Safety and efficacy of direct-acting antivirals for chronic hepatitis $\mathrm{C}$ in patients with chronic kidney disease. BMC Nephrol., 21(1):21-26.

14. Mazumdar B, Kim H, Meyer K, Bose SK, Di Bisceglie AM, Ray RB and Ray R.(2012): Hepatitis C virus proteins inhibit C3 complement production. J Virol., 86(4):2221-8.

15. Ruane PJ, Ain D, Stryker R, Meshrekey R, Soliman M, Wolfe PR, Riad J and Mikhail S (2015): Sofosbuvir plus ribavirin for the treatment of chronic genotype 4 hepatitis C virus infection in patients of Egyptian ancestry. J Hepatol., 62(5):1040-6.

16. Van der Meer AJ, Veldt BJ, Feld JJ, Wedemeyer H, Dufour JF, Lammert F, Duarte-Rojo A and Heathcote EJ (2012): Association between sustained virological response and all-cause mortality among patients with chronic hepatitis $\mathrm{C}$ and advanced hepatic fibrosis. JAMA., 308(24):2584-93.

17. Vanni E, Bugianesi E and Saracco G (2015): Treatment of type 2 diabetes mellitus by viral eradication in chronic hepatitis C: Myth or reality? Dig Liver Dis., 48(2):105-11.

18. Webster DP, Klenerman $P$ and Dusheiko GM (2015): Hepatitis C. Lancet, 385(9973):1124-35. 
تقييم مستوى المتممان سي 3 وسي 4 بالمصل في الإصـابة

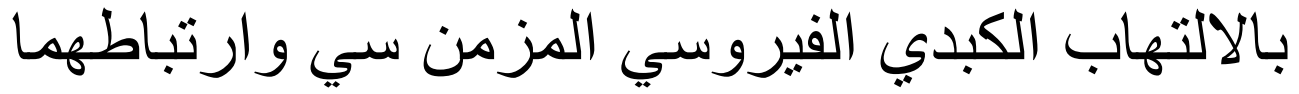
بالاستجابة للعلاج بمضادات الفيروسات المبات المباشرة محمد عبد الواحد رمضان1، صباح ابراهيم عبد الرحيم²، أحمد السعيد السحراوي3،

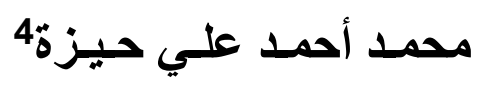
1قسم الباتولوجيا الإكلينيكية، كلية طب دمياط، جامعة الأزهر، مصر

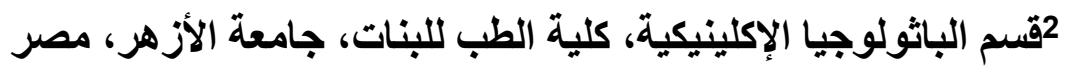
3قسم الباثولوجيا الإكلينيكية، كلية الطب، جامعة الأزهر، مصر

E-mail: dr.mohamedabdelwahed92@gmail.com

4قسم أمر اض الكبد والجهاز الهضمي والأمراض المعدية، كلية طب دمياط، جامعة الأزهر، مصر

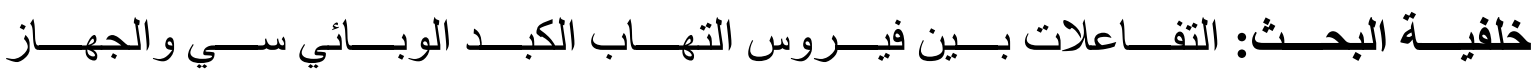

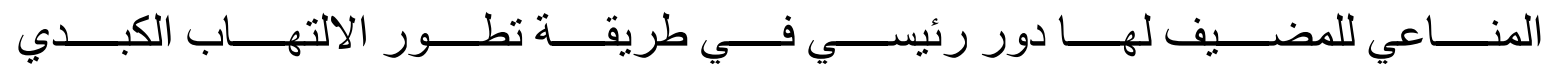

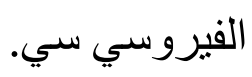

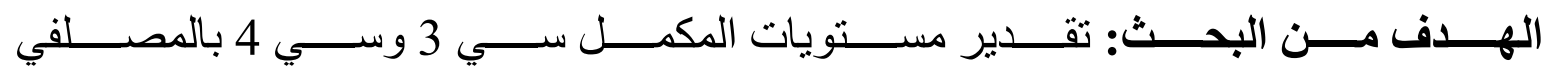

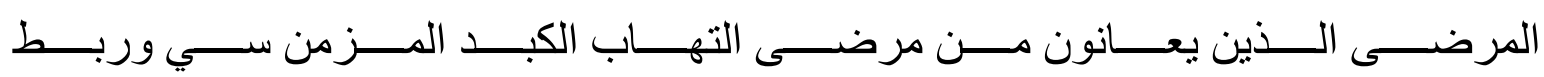

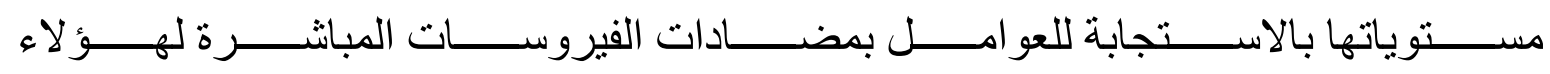

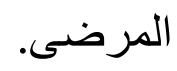

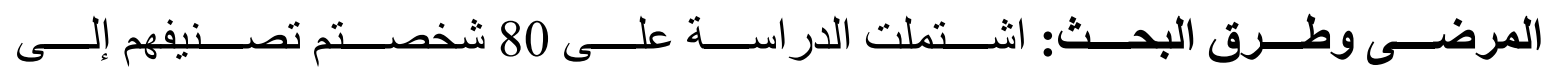

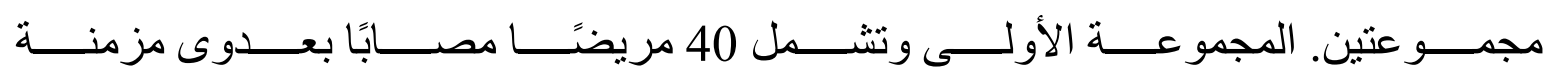

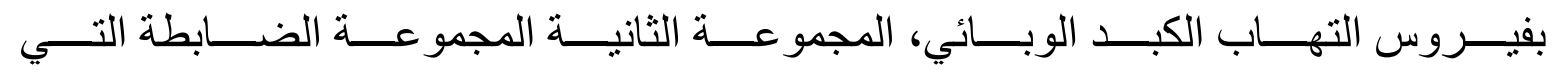

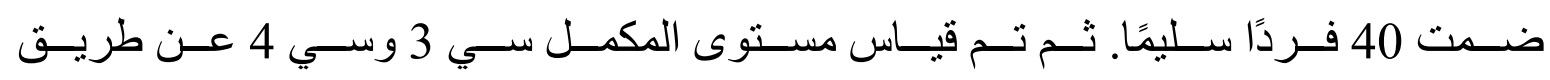
المقايسة المناعية قبل وبعد العلاج بمضادات الفيروسات المبانشرة.

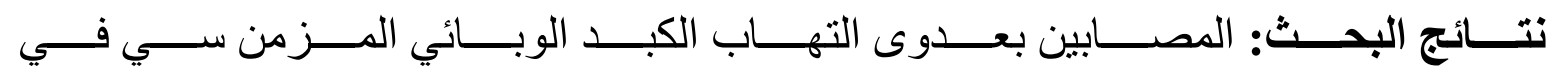

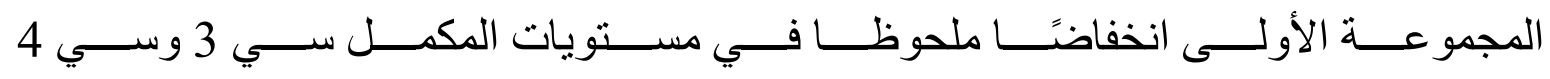




\section{MOHAMED ABD EL-WAHED RAMADAN et al.,}

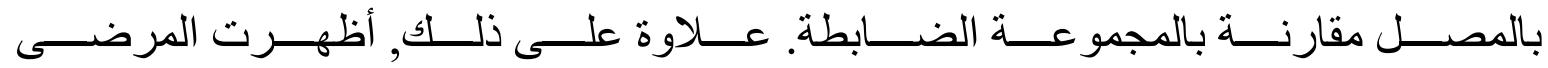

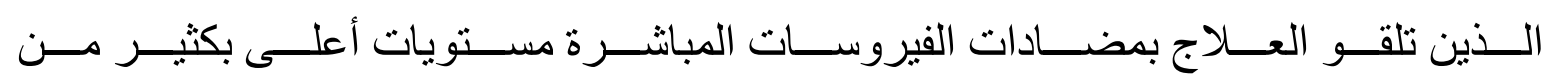

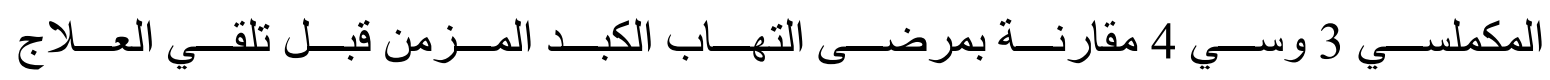
بمضادات الفيروسات المباشرة.

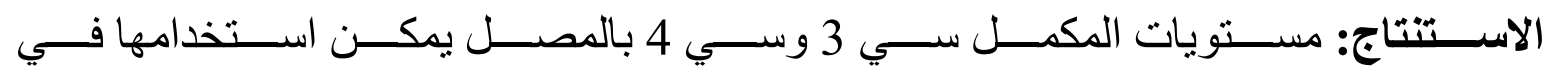

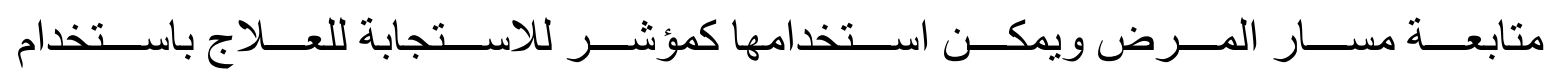
مضادات الفيروسات المباثرة.

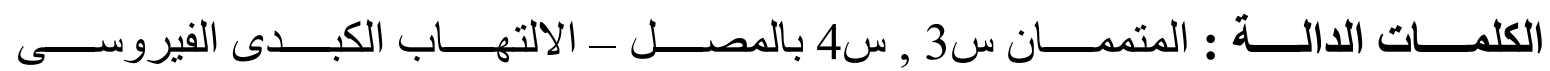
المزمن س ـ مضادات الفيروسى . لكئ. 